\title{
INSTYTUCJA WSPÓŁDZIAŁANIA MATERIALNEGO W WYDAWANIU AKTÓW ADMINISTRACYJNYCH NA PRZYKŁADZIE WYBRANYCH PORZĄDKÓW PRAWNYCH - POLSKI I REPUBLIKI FEDERALNEJ NIEMIEC ${ }^{* *}$
}

\section{WPROWADZENIE}

W polskim porządku prawnym można wyróżnić dwa rodzaje współdziałania: współdziałania materialne i współdziałanie procesowe. Współdziałanie materialne, jak wskazuje Barbara Adamiak, polega na uzależnieniu rozstrzygnięcia sprawy od zajęcia stanowiska przez inny organ przez wyrażenie opinii, zgody, uzgodnienia, porozumienia a podstawa do jego stosowania znajduje się $\mathrm{w}$ prawie materialnym ${ }^{1}$, natomiast jego granice wyznacza art. 106 k.p.a. Współdziałanie procesowe obejmuje takie instytucje jak pomoc prawna z art. 52 k.p.a., a także żądanie przedstawienia przez organ administracji publicznej od innego organu administracji publicznej odpisu lub wyciagu dokumentu, jeżeli strona nie może go uzyskać, żądania dostarczenia przez organ oryginału dokumentu, jeżeli zachodzi konieczność jego przejrzenia art. 76a $\S 1$ k.p.a. Współdziałanie procesowe podejmowane jest nie w celu uzgodnienia treści aktu administracyjnego, jak w przypadku współdziałania materialnego, ale dla ustalenia stanu faktycznego w zakresie faktów, które można pozyskać za pomoca współdziałania z innymi organami administracji publicznej.

Przedmiotem artykułu jest współdziałanie materialne i problemy związane $\mathrm{z}$ określeniem formy i charakteru prawnego aktu zajęcia stanowiska wydanego przez organ współdziałający, efektywnością wykorzystania instytucji

* Lucyna Staniszewska, Uniwersytet im. Adama Mickiewicza w Poznaniu, lucynast@amu.edu.pl, https://orcid.org/0000-0003-3457-0901.

** Artykuł powstał w wyniku stażu naukowego sfinansowanego w ramach konkursu ze środków statutowych Wydziału Prawa i Administracji UAM.

1 Adamiak (2019): 83. 
współdziałania materialnego, statusem organu obowiązanego do zajęcia stanowiska w postępowaniu głównym, a także ochroną stron postępowań głównych przed niekorzystnym aktem współdziałania. Porównanie regulacji polskiej z niemiecka ma na celu ocenę rozwiązań przyjętych $\mathrm{w}$ analizowanych porządkach prawnych oraz sformułowanie postulatów co do potrzeby ewentualnych zmian legislacyjnych w prawie polskim bądź w praktyce stosowania instytucji współdziałania przez polskie organy administracji publicznej.

$\mathrm{W}$ niemieckiej ustawie o postępowaniu administracyjnym (Verwaltungsverfahrensgesetz, $\mathrm{Vw}_{\mathrm{w}} \mathrm{GG}^{2}$ ) niestety nie ma jednego przepisu, który kompleksowo regulowałby współpracę różnych organów publicznych lub agencji publicznych. Ustawa proceduralna VwVfG zawiera tylko niektóre zasady współdziałania na potrzeby konkretnych ich form. Najważniejsze normy są często rozrzucone w ustawach prawa materialnego. Regulacje takie stanowi federalny kodeks budowlany (Baugesetzbuch, BauGB ${ }^{3}$ ). Jednakże instytucja współdziałania $\mathrm{w}$ prawie niemieckim jest pozytywnie oceniana $\mathrm{w}$ doktrynie, ponieważ nie spowalnia procedowania przez organy administracji. Natomiast w Polsce, pomimo uregulowania proceduralnych aspektów współdziałania w k.p.a., na skutek problemów związanych z terminowością wydania aktów współdziałania, a niekiedy niską ich wartością dla wyczerpującego wyjaśnienia sprawy, ustawodawca zdecydował się na wprowadzenie instytucji posiedzenie w celu współdziałania w art. 106a k.p.a., aby usprawnić procedurę współdziałania, a także stworzyć warunki do wspólnego dochodzenia do rozwiązań przez organy współdziałające ${ }^{4}$. Kolejnym hamulcem do rozwoju współdziałania w prawie polskim może być brak ponoszenia odpowiedzialności odszkodowawczej przez organ współdziałający za niezgodne z prawem stanowisko, także jeśli jest stanowcze i kształtuje treść rozstrzygnięcia.

\section{CHARAKTER PRAWNY MATERIALNOPRAWNEGO WSPÓŁDZIAŁANIA I JEGO EFEKTYWNOŚĆ}

Samo pojęcie współpracy organów administracji publicznej nie jest jednoznacznie nazywane ani też rozumiane w doktrynie polskiej, ani niemieckiej. Dla oznaczenia różnych form współdziałania używane są różne określenia, takie jak: „administracja wielopoziomowa” (niem. Mehrebenenverwaltung), „związek administracyjny, czy stowarzyszenie” (niem. Verwaltungsverbund),

${ }^{2}$ Zob. <https://www.gesetze-im-internet.de/vwvfg/> [dostęp: 15.05.2020].

${ }^{3}$ Ustawa federalny kodeks budowlany - Baugesetzbuch in der Fassung der Bekanntmachung z 3 listopada 2017 r. (BGBl. I S. 3634).

${ }^{4}$ Ustawa z 14 czerwca 1960 r. - Kodeks postępowania administracyjnego: t.jedn.: Dz. U. 2018, poz. 2096 (dalej: jako: k.p.a.). Brak stanowiska organu współdziałającego uniemożliwia wydanie decyzji przez organ ,główny” (załatwiający sprawę), a w konsekwencji prowadzi do sytuacji, w której oba te organy będą narażone za zarzut przewlekłego prowadzenia postępowania - argument podnoszony w uzasadnieniu projektu ustawy: Zmiana ustawy - Kodeks postępowania administracyjnego oraz niektórych innych ustaw, Druk sejm. VIII.1183, Lex. 
„wspólnota administracyjna” (niem. Verwal-tungsgemeinschaft) czy „administracja mieszana" (niem. Mischverwaltung). Natomiast efekty współdziałania w postaci aktów administracyjnych doktryna niemiecka nazywa Mehrstufige verwaltungsakte, czyli akty wielopoziomowe w opozycji do aktów nazywanych einstufige verwaltungsakte, tzw. jednopoziomowych. W prawie polskim, w przeciwieństwie do niemieckiego, nie wyróżnia się odrębnych nazw własnych dla aktów administracyjnych wydawanych przez jeden organ ani też przez kilka organów we współdziałaniu. Wyróżnia się natomiast różne określenia na same formy zajęcia stanowiska, takie jak: opiniowanie, uzgodnienie, konsultowanie, wyrażanie zgody. W nauce przeważa stanowisko, zgodnie z którym współcześnie możemy mówić o ukształtowaniu się prawa współpracy administracyjnej (niem. Kooperationsverwaltungsrecht) ${ }^{5}$.

W Niemczech wyróżnia się zarówno akty „jednopoziomowe”, wydawane przez jeden organ administracji publicznej, jak i ,,wielopoziomowe” akty administracyjne, w których wydanie zaangażowanych jest kilka organów. Celem wydania aktu wielopoziomowego współdziałać muszą co najmniej dwa organy administracji publicznej, a każdy z organów posiada własne kompetencje. Istotną kwestią jest jasne określenie granic kompetencyjnych przez organy: główny i pomocniczy. Współdziałania dokonuje organ pomocniczy w zakresie swej właściwości, ale także swoich kompetencji. Podobnie w regulacji polskiej każdy z organów zaangażowanych we współdziałanie materialne musi przestrzegać w niej swoich kompetencji. Organ prowadzący postępowanie $\mathrm{w}$ sprawie nie może wkraczać $\mathrm{w}$ kompetencje organu z nim współdziałającego, a organ współdziałający nie może realizować swoich kompetencji w szerszym zakresie niż przyznany mu w ustawie, niezależnie od tego, która $\mathrm{z}$ form współdziałania przewidziana prawem materialnym jest realizowana w konkretnym przypadku ${ }^{6}$. W doktrynie polskiej wskazuje się, że współdziałanie organów administracji publicznej polega na tym, że w jednej sprawie przecinają się zakresy działania dwóch lub więcej organów administracji publicznej, z których jednemu ustawodawca powierzył rolę wydania decyzji końcowo rozstrzygającej sprawę (organ główny), a drugiemu (pomocniczy) wyznaczył rolę wydania aktu uczestnictwa ${ }^{7}$.

Rozważania na temat aktów współdziałania zaczać należy od próby wyjaśnienia i zdefiniowania współdziałania w stosowaniu i stanowieniu prawa przez administrację publiczną. Współdziałanie to jedna z występujących już tradycyjnie form stosunków $\mathrm{w}$ ramach administracji publicznej. Zbigniew Niewiadomski wymienia ja obok kierownictwa, koordynacji, nadzoru i kontroli $^{8}$. Wyjściową kwestią dla definiowania współdziałania, jak wskazuje się $\mathrm{w}$ doktrynie, musi być pojęcie więzi prawnych pomiędzy organami administracji publicznej ${ }^{9}$. Więzi ujawniają się przy badaniach nad strukturą apara-

${ }^{5}$ Wegner (2016): 32.

${ }^{6}$ Wyroki WSA w Warszawie: z 3 kwietnia 2007 r., IV SA/Wa 117/07, Lex nr 337785; z 23 kwietnia 2009 r., IV SA/Wa 89/09, Lex nr 550244.

7 Szewczyk (2019): 88.

${ }^{8}$ Niewiadomski (2011): 87.

${ }^{9}$ Błachucki (2019): 93. 
tu administracji publicznej i stosunków między jej poszczególnymi ogniwami. Administracja publiczna stanowi pewien system organów, które połączone sa różnymi relacjami, nazywanymi także więziami prawnymi organizacyjnymi i pozaorganizacyjnymi ${ }^{10}$. Takie więzi pozaorganizacyjne moga przyjmować różną postać (np. nadzoru, koordynacji, kontroli, lecz także i współdziałania). Współdziałanie zatem jest rodzajem więzi pozaorganizacyjnych zewnętrznych, łączących podmioty niezależne organizacyjnie, niepodlegające sobie służbowo.

Stanisław Biernat za administracyjne działania wspólne uważa wspólne oświadczenia woli co najmniej dwóch podmiotów administracji publicznej, które mają na celu wywołanie skutków prawnych w obrębie prawa administracyjnego ${ }^{11}$. Mając na uwadze cechy współdziałania w ogólności, można zdefiniować współdziałanie w wydawaniu aktów administracyjnych w ujęciu materialnoprawnym w prawie polskim jako formę nakazanej prawem materialnym, obowiązkowej współpracy ze sobą co najmniej dwóch podmiotów administracji publicznej, które nie sa powiązane organizacyjnie i są od siebie niezależne, w celu wydania przez kompetentny do tego jeden organ tzw. głównego aktu zewnętrznego stanowienia bądź stosowania prawa, będącego wynikiem wspólnego stanowiska właściwych organów, który to akt wywołuje skutki prawne w obrębie prawa administracyjnego. Natomiast sam akt organu współdziałającego najczęściej uzewnętrzniony jest w formie postanowienia, o czym stanowi art. 106 k.p.a., w przypadku współdziałania w stanowieniu aktów stosowania prawa. Wątpliwości wzbudza stosowanie tej podstawy do aktów stanowienia prawa, albowiem k.p.a. ma zastosowanie do postępowań jurysdykcyjnych w sprawach indywidualnych, a nie do postępowań zmierzających do wydania aktów generalnych czy normatywnych. Niemniej przepisy prawa materialnego co do zasady odsyłają do stosowania art. 106 k.p.a. do współdziałania w stanowieniu prawa.

Samo postępowanie przed organem współdziałającym pełni pomocnicza funkcję w sprawie głównej. Postępowanie takie oraz wydane w jego toku postanowienie nie ma samodzielnego i niezależnego od postępowania głównego bytu prawnego, tak jak w przypadku postępowań zależnych ${ }^{12}$.

Zarówno w Polsce, jak i w Republice Federalnej Niemiec wyróżnia się bardzo wiele rodzajów współdziałania. Niektóre z nich ze względu na swoją siłę sa aktami wiążącymi dla organu głównego, inne mają charakter czysto doradczy i niewiążący, a wręcz stanowią rodzaj nieformalnej współpracy. W prawie polskim ze względu na charakter i siłę współdziałania wyróżnia się różne ich nazwy takie jak: opinie, uzgodnienia, porozumienia, zgody $^{13}$. Ich podstawy prawne wynikaja z norm prawa materialnego, natomiast procedura podejmowania znajduje uregulowanie w przepisach polskiego Kodeksu postępowania administracyjnego. Przepisy proceduralne nie moga jednak stanowić samodzielnej podstawy rozstrzygnięcia podejmowanego przez organ współdziałający ${ }^{14}$.

\footnotetext{
10 Rybicki (1984): 249.

11 Biernat (1979): 23.

12 Szewczyk (2019): 80.

13 Pawłowski, Staniszewska (2018): 375.

14 Wyrok NSA z 5 lipca 2001 r., IV SA 323/99, Lex nr 79343.
} 
Wskazuje się w prawie polskim na następująca gradację form współdziałania. Za pomoca zwrotów: ,za zgoda”, „w porozumieniu”, „po uzgodnieniu” oznacza się współdziałanie obowiązkowe, czyli takie, które jest nie tylko niezbędne dla wydania rozstrzygnięcia, ale także oznacza, że jedynie zbieżność stanowiska organu wydającego decyzję i współdziałajacego stanowi warunek konieczny wydania rozstrzygnięcia. Przykładowo w ustawie z 21 sierpnia $1997 \mathrm{r}$. o gospodarce nieruchomościami ${ }^{15}$, w art. 46 ust. 4 pkt $1-5^{16}$, wymieniono podmioty, w przypadku których decyzja o wygaśnięciu przysługującego im prawa trwałego zarządu nieruchomościa wymaga zgody wojewody, przy czym zgoda taka ma w każdym przypadku być wydawana przez wojewodę w porozumieniu z właściwym ministrem lub szefem właściwej służby. Powinna mieć ona formę postanowienia zgodnie z art. $106 \S 5$ k.p.a. Jest to przykład współdziałania w wydaniu aktu indywidualnego, najsilniejszego, wymagającego pełnej zbieżności woli, przejawiającej się w obowiązku dojścia do zgody dwóch organów.

Innym przykładem współdziałania w wydaniu aktu indywidualnego jest regulacja z art. 39 ust. 3 ustawy z 7 lipca 1994 r. - Prawo budowlane ${ }^{17}$, w którym wskazano, że w stosunku do obiektów budowlanych oraz obszarów niewpisanych do rejestru zabytków, a ujętych w gminnej ewidencji zabytków, pozwolenie na budowę lub rozbiórkę obiektu budowlanego wydaje organ administracji architektoniczno-budowlanej w uzgodnieniu z wojewódzkim konserwatorem zabytków.

Natomiast za pomoca zwrotów ,,po zasięgnięciu opinii” i ,,po konsultacji” oznacza się współdziałanie, które polega na tym, że organ w sprawie głównej przed podjęciem decyzji jest zobowiązany do zasięgnięcia stanowiska innego organu, jednakże nie jest on prawnie związany zajętym stanowiskiem organu opiniującego czy konsultującego. Jest to swoisty rodzaj doradztwa, niemający wiążacego charakteru dla organu wydającego akt administracyjny ${ }^{18}$. Najluźniejszą formą współdziałania organów administracji publicznej jest współdziałanie polegające na zasięgnięciu opinii. Współdziałanie takie polega na tym, że jeden z organów jest zobowiązany przed podjęciem decyzji do zasięgnięcia opinii innego organu. Organ zobowiązany do zasięgnięcia opinii nie jest prawnie związany stanowiskiem organu opiniującego. Mówiąc o współdziałaniu organów administracji, należy zatem każdorazowo zwrócić uwagę, że jego zakres został przez ustawodawcę zróżnicowany.

15 T.jedn.: Dz. U. 2020, poz. 65.

${ }_{16}$ Art. 46 ust. 4 stanowi, że decyzja o wygaśnięciu trwałego zarządu przysługującego jednostkom organizacyjnym: 1) resortu obrony narodowej - wymaga zgody wojewody, wydanej w porozumieniu z ministrem właściwym do spraw obrony narodowej; 2) resortu spraw wewnętrznych - wymaga zgody wojewody, wydanej w porozumieniu z ministrem właściwym do spraw wewnętrznych; 3) resortu sprawiedliwości - wymaga zgody wojewody, wydanej w porozumieniu z ministrem właściwym do spraw sprawiedliwości; 4) Agencji Bezpieczeństwa Wewnętrznego lub Agencji Wywiadu - wymaga zgody wojewody, wydanej w porozumieniu odpowiednio z Szefem Agencji Bezpieczeństwa Wewnętrznego lub Szefem Agencji Wywiadu; 5) Centralnego Biura Antykorupcyjnego - wymaga zgody wojewody, wydanej w porozumieniu z Szefem Centralnego Biura Antykorupcyjnego.

17 Ustawa z 7 lipca 1994 r. - Prawo budowlane, t.jedn.: Dz. U. 2019, poz. 1186.

18 Leoński, Szewczyk, Kruś (2019): 294 i 313. 
Na przykładzie współdziałania organów administracji w sprawie wydawania decyzji o środowiskowych uwarunkowaniach można rozważyć jego sprawność i efektywność. Ustawodawca w art. 77 ustawy środowiskowej ${ }^{19}$ wprowadza szeroki katalog organów współdziałających. W przypadku uzgodnienia organy współdziałające powinny osiagnać porozumienie, konsens co do warunków realizacji przedsięwzięcia, natomiast w przypadku opinii organ główny nie jest związany stanowiskiem i może rozstrzygać odmiennie $\mathrm{w}$ stosunku do tego stanowiska ${ }^{20}$. W związku $\mathrm{z}$ tym $\mathrm{w}$ procedurze $\mathrm{w}$ danej sprawie może dojść do wydania kilku wiążących uzgodnień, które będą ze sobą sprzeczne. W takim przypadku organ rozstrzyga te sprzeczności w terminie 14 dni od dnia otrzymania uzgodnień, po uprzednim porozumieniu z organami, których uzgodnienia były ze sobą sprzeczne, i uwzględnia to rozstrzygnięcie $\mathrm{w}$ decyzji kończącej postępowanie, wydanej $\mathrm{w}$ terminie 30 dni od dnia otrzymania uzgodnienia organów (art. 77 ust. 9 ustawy środowiskowej). Biorąc pod uwagę terminy procedowania nad zajęciem stanowiska przez organy współdziałające, które mają charakter instrukcyjny, a ich przekroczenie upoważnia jedynie do wniesienia ponaglenia, a także konieczność dalszego procedowania organu głównego w zakresie porozumienia się z organami, które wydały sprzeczne uzgodnienia już po ich doręczeniu, znacząco wydłuża się procedowanie w sprawie głównej. Poprawie efektywności tego rodzaju działań może posłużyć instytucja posiedzenia w celu współdziałania zawarta w art. 106 a k.p.a.

Niestety w prawie polskim brakuje posługiwania się przez ustawodawcę spójną koncepcją form współdziałania, a także jednolita procedurą ${ }^{21}$. Powoduje to, że ustawodawca stanowi je bezrefleksyjnie z pominięciem różnic pomiędzy poszczególnymi postaciami współdziałania, wynikający z nich skutków prawnych. Zarówno uzgodnienie stanowiska przez organy, jak i zgoda powinny stanowić formę bardzo ścisłej więzi i współpracy pomiędzy organami sprowadzającej się wręcz do współdecydowania. Trafnie wskazał Krystian Ziemski, że jeśli organ główny wydaje akt negatywny, pomimo zgody innego organu, trudno przyjąć, aby organ współdziałający współdecydował ${ }^{22}$. W sposób nieprawidłowy często ustawodawca wybiera formę uzgodnienia, która nie stanowi jednostronnego stanowiska organu współdziałającego, ale powinna prowadzić do wspólnych działań w celu wypracowania treści decyzji głównej.

Zasadniczo także w prawie niemieckim istnieją różne formy współpracy między organami publicznymi ${ }^{23}$. Niekiedy wymagane jest „Einvernehmen” (,zatwierdzenie”) treści rozstrzygnięcia aktu głównego. Organ główny musi wówczas dojść do porozumienia z innym organem, którego stanowisko jest po-

${ }^{19}$ Ustawa z 3 października 2008 r. - o udostępnianiu informacji o środowisku i jego ochronie, udziale społeczeństwa w ochronie środowiska oraz o ocenach oddziaływania na środowisko, t.jedn.: Dz. U. 2020, poz. 283 (dalej jako: ustawa środowiskowa).

${ }^{20}$ Wyrok NSA z 1 lipca 2016 r., II OSK 339/15, Legalis.

${ }^{21} \mathrm{~W}$ stosunku do większości przykładów współdziałania zastosowanie znajduje regulacja proceduralna $\mathrm{z}$ art. 106 k.p.a., zdarzają się jednak także odmienności w tym zakresie, np. w art. 89 ustawy z 8 marca 1990 r., t.jedn.: Dz. U. 2020, poz. 713.

${ }^{22}$ Ziemski (1996): 91.

${ }^{23}$ Erbguth (2017): 114. 
trzebne. W takim przypadku zatwierdzenie przez inny organ jest obowiązkwe, a organ główny może wydać akt administracyjny tylko wtedy, gdy uzyska takie zatwierdzenie. Podobnie jeśli ustawa stanowi o „Zustimmung” (,umowie”), organ główny może działać tylko wtedy, gdy inny organ wyraził wcześniej zbieżne stanowisko z organem głównym. Jeśli natomiast wystarczające jest uzyskanie konsultacji „Benehmen”, standard jest jednak inny: w tym przypadku organ odpowiedzialny za akt główny musi jedynie skonsultować się z innym organem. Jeżeli organ współdziałający wypowie się negatywnie, organ główny może mimo to wydać pozytywny akt administracyjny, o ile w dobrej wierze starał się znaleźć porozumienie z innym organem.

Wreszcie w prawie niemieckim występuje pojęcie generalne „Mitwirkung” (,współpraca”) jest to termin obejmujący wszelkie formy współdziałania materialnego i stanowi odpowiednik stanowiska i może oznaczać „Einvernehmen”, „Zustimmung” lub „Benehmen”.

Kodeks postępowania administracyjnego (VwVfG) stanowi w $§ 58$ ust. 2, dotyczącym zawierania umów publicznoprawnych na podstawie zamówienia publicznego, że jeżeli zamiast aktu administracyjnego zostanie zawarta umowa, której wydanie z mocy prawa wymagałoby przyjęcia porozumienia lub zatwierdzenia innego organu, umowa staje się ważna, gdy inny organ wyda zgodę w przewidzianej formie, tj. „Einvernehmen”.

W odniesieniu do specjalnych procedur zatwierdzania aktu planistycznego, $§ 78$ ust. 2 zd. 2 VwVfG stanowi, że „Einvernehmen” (tutaj tłumaczone jako „umowa”) musi zostać zawarta w przypadku niepewności co do tego, który przepis prawny ma zastosowanie, i jeśli zgodnie z odpowiednimi przepisami organ federalny i organ kraju związkowego są właściwe, a najwyższe organy federalne i władze kraju związkowego nie są w stanie osiagnać porozumienia, rząd federalny i kraju związkowego zawierają umowę dotyczącą tego, który przepis prawny ma zastosowanie.

Natomiast jedyny przykład „Benehmen” („konsultacja”) na gruncie ustawy proceduralnej VwVfG można znaleźć w części dotyczącej specjalnych procedur zatwierdzania planu dla dewelopera, w $§ 74$ ust. 6 VwVfG, który stanowi, że „Benehmen” („konsultacje”) należy przeprowadzić przed wydaniem zgody na planowaną inwestycję, jeżeli: 1) nie dochodzi do naruszenia praw innych osób lub gdy osoby, których to dotyczy, oświadczyły na piśmie, że wyrażają zgodę na wykorzystanie ich własności lub niektórych innych praw; oraz 2) osiagnięto porozumienie z tymi agencjami publicznymi, których zakres kompetencji zostałby naruszony.

Natomiast w prawie materialnym ,Einvernehmen” został uregulowany w art. $§ 5$ ust. 4 ustawy federalnej o drogach (FStrG $)^{24}$, zgodnie z którym trasę głównej drogi przez najwyższy organ budujący drogi (Landesstraßenbaubehörde) ustala się w porozumieniu z wyższym organem administracyjnym (Verwaltungsbehörde) po konsultacjach ,Benehmen” ze społecznością lokalną. W doktrynie niemieckiej wskazuje się, że porozumienie między organami ma charakter wspólnego dochodzenia do najlepszych rozwiązań, prowadzenia roz-

${ }^{24}$ Ustawa federalne prawo o drogach (Bundesfernstraßengesetz FStrG) z 6 sierpnia 1953 r., BGBl. I S. 2237. 
mów, rokowań, korygowania stanowisk pod kątem różnych grup interesów ${ }^{25}$. Regulację współdziałania zawiera także $§ 14$ ustawy o transporcie pasażerskim (PBefG) ${ }^{26}$, który stanowi, że wydanie decyzji w sprawie wniosku o zezwolenie na przewóz pasażerów tramwajem, trolejbusem lub zwykłym pojazdem silnikowym wymaga przez organ udzielający zezwolenia konsultacji z operatorami obsługującymi pojazdy szynowe, tramwajowe, trolejbusowe lub regularne pojazdy silnikowe na obszarze objętym wnioskiem, a także uzyskania opinii gmin na obszarze zajezdni ruchu.

Natomiast w § 44 i 45 VwVfG ustanowiono zasady dotyczące konsekwencji braku uzyskania bądź pominięcia aktów uczestnictwa organu współdziałającego. Zgodnie z $§ 44$ ust. $3 \mathrm{nr} 3,4 \mathrm{VwVfG}$ decyzja może być niezgodna z prawem (a zatem może być zaskarżona w sądzie), ale nigdy nie będzie uważana za nieważną tylko dlatego, że nie doszło do współdziałania innych organów. Zgodnie z § 45 ust. $1 \mathrm{nr} 4,5 \mathrm{VwVfG}$ brak „współpracy” innych organów można sanować, a zatem można uznać za nieistotny, jeżeli „współpraca” została później podjęta (nawet podczas postępowania sądowego przeciwko aktowi administracyjnemu). Zgoda właściwego organu na wydanie określonego aktu administracyjnego w późniejszym terminie lub odmowa (poświadczenie) muszą być dokonane na piśmie, aby były ważne. Ponadto organ współdziałający może prowadzić postępowanie wyjaśniające, sprowadzające się przykładowo do wysłuchania stron.

Wspólną cechą tych wszystkich form współdziałania w analizowanych porządkach prawnych jest to, że organem odpowiedzialnym za podjęcie aktu jest organ prowadzający postępowanie w sprawie głównej, natomiast organ współdziałający ma wyrazić własne stanowisko poparte szczególną wiedzą i doświadczeniem. Zwrócić jednak należy szczególną uwagę, że bez względu na siłę współdziałania nie powinno sprowadzać się ono jedynie do zajęcia stanowiska, ale do wspólnego rozważania danego problemu przez co najmniej dwa organy. Powinno w nim mieścić się wspólne aktywności organów, przez rozmowy, konsultacje, wymianę stanowisk, prowadzące do przekonania przez organ współdziałający organu głównego oraz stron postępowania do określonego stanowiska. Takie współdziałanie służy przyspieszeniu postępowania, a także lepszemu wyjaśnieniu stanu faktycznego i prawnego. Wówczas brak podstaw do krytycznej oceny współdziałania jako zbędnego elementu postępowania głównego.

\section{WSPÓŁDZIAŁANIE A OCHRONA STRONY I TRYB KONTROLI AKTÓW WSPÓŁDZIAŁANIA}

W polskim porządku prawnym organy administracji publicznej są obowiązane do zapewnienia stronom czynnego udziału w każdym stadium postępowania, w tym również dotyczącym wydania postanowienia na podstawie art. 106 k.p.a.

${ }^{25}$ Müller (2008): 57.

${ }^{26}$ Ustawa o transporcie pasażerskim (Personenbeförderungsgesetz in der Fassung der Bekanntmachung z 8 sierpnia 1990 r. ([BGBl. I S. 1690]). 
Strony maja prawo do udziału w postępowaniu prowadzonym przed organem współdziałajacym ${ }^{27}$. Natomiast w orzecznictwie brak jednolitego stanowiska co do ustalania kręgu stron postępowania uzgodnieniowego ${ }^{28}$. Przeważa pogląd, że krag osób, których interesu prawnego dotyczy postępowanie uzgodnieniowe, jest taki sam jak postępowania w sprawie głównej, a zatem jest w sposób wiążący ustalany przez organ główny ${ }^{29}$. Inny pogląd zaprezentował WSA w Krakowie, wskazując, że chociaż organ uzgadniający może oprzeć się na wykazie stron przekazanym mu przez organ prowadzący postępowanie główne, jednakże nie jest nim związany i w sytuacji wpłynięcia pisma pochodzącego od osoby nieujętej w dotychczasowym wykazie stron, jest zobowiązany do zbadania, czy osoba taka jest stroną postępowania w rozumieniu art. 28 k.p.a. ${ }^{30}$ Drugie stanowisko wydaje się trafne ze względu na ochronę praw jednostek, jak i autonomiczność postępowania przed organem współdziałajacym.

Problematyka umożliwienia stronom czynnego udziału przez organ współdziałający powinna być przedmiotem oceny organu głównego, zwłaszcza w przypadku tych aktów współdziałania, co do których nie przysługuje zażalenie $^{31}$. W przypadku stwierdzenia nieprawidłowości w tym zakresie organ główny powinien podjać próbę ich konwalidacji, np. przez doręczenie stronom nieuczestniczacym w postępowaniu przed organem współdziałającym wydanych postanowień. Niewątpliwie poczyniłoby się to do przyspieszenia postępowania głównego, którego załatwienie jest paraliżowane kwestionowaniem nawet w trybie wznowieniowym aktu wiążącego współdziałania ${ }^{32}$.

Rzetelna weryfikacja katalogu stron postępowania przez organ główny jest szczególnie istotna, zwłaszcza w przypadku regulacji autonomicznych współdziałania względem art. 106 k.p.a., mocą których strony nie mają prawa do odrębnego zaskarżenia aktów uczestnictwa. Przykładowo ustawodawca w art. 53 ust. 5 u.p.z.p. ${ }^{33}$ pozbawił inne (poza inwestorem) strony postępowania możliwości zaskarżenia postanowienia uzgadniajacego warunki zabudowy.

Ze względu na utrwaloną w orzecznictwie potrzebę rygorystycznego pojmowania i przestrzegania zasady czynnego udziału strony w każdym stadium postępowania nie ma podstaw do różnicowania uprawnień strony w zależności od tego, czy już wcześniej występowała w postępowaniu głównym, czy też ujawniła się ona dopiero na etapie postępowania incydentalnego ${ }^{34}$.

27 Wyroki WSA w Warszawie: z 14 lipca 2005 r., IV SA/Wa 716/05, Legalis; z 7 lutego 2007 r., IV SA/Wa 2314/06, Legalis.

28 Romańska (2019): 154.

${ }^{29}$ Wyrok WSA w Warszawie z 14 lipca 2005 r., IV SA/Wa 716/05, Lex nr 190566; wyrok NSA z 15 marca 2012 r., II OSK 2538/10, Lex nr 1251971.

${ }^{30}$ Wyrok WSA w Krakowie z 7 listopada 2008 r., II SA/Kr 811/08, Lex nr 532831.

31 Przykładowo, zgodnie z art. 77 ust. 7 ustawy środowiskowej wyłączono możliwość wniesienia od aktów uczestnictwa wydanych w toku postępowania o wydanie decyzji środowiskowej zażalenia (zgodnie z art. $141 \S 1$ k.p.a. uprawnienie to przysługuje, gdy kodeks lub inny akt prawny tak stanowi).

32 Gruszecki (2020): 141.

${ }^{33}$ Ustawa z 27 marca 2003 r. - o planowaniu i zagospodarowaniu przestrzennym, t.jedn.: Dz. U. 2018, poz. 1945.

34 Wyrok WSA w Warszawie z 4 września 2007 r., IV SA/Wa 926/07, Lex nr 372415. 
Natomiast w przypadku prawa niemieckiego w samej procedurze przepis $\S 38$ ust. 1 i 2 VwVfG wprost stanowi, że strony maja prawo do czynnego udziału w postępowaniu organu współdziałającego. W doktrynie niemieckiej wskazuje się, że w przypadku regulacji prawnej stanowiącej o decyzji wymagającej współdziałania innego organu należy najpierw rozważyć, czy taka instytucja nie może być uznana za decyzję złożoną (tj. wspólny akt tych organów, podejmowany w ramach jednego postępowania), wówczas akt współdziałania jest aktem wyłącznie wewnętrznym ${ }^{35}$. Wielopoziomowy akt administracyjny polega na tym, że organ może działać zewnętrznie, tj. w stosunku do obywatela (organ decyzyjny), po uprzednim wewnętrznym podjęciu rozstrzygnięcia przez inny organ (tzw. organ partycypacyjny). Oznacza to, że właściwy organ współdziałający nie może wydać rozstrzygnięcia kierowanego do jednostek, czyli na zewnętrz administracji. Wielopoziomowy akt administracyjny ma miejsce, gdy kilka organów uczestniczy w kształtowaniu treści rozstrzygnięcia, a ich stanowiska muszą być zgodne, aby wydać wspólny akt administracyjny.

W doktrynie niemieckiej w latach pięćdziesiątych i sześćdziesiątych XX w. wyjaśniono, że akty współpracy organów administracji publicznej związane $\mathrm{z}$ wydaniem indywidualnych aktów administracyjnych maja prawnie konstytutywny skutek i składaja się na akt wielopoziomowy ${ }^{36}$. Akty współdziałania sa kontrolowane w Niemczech przez Są Administracyjny w ramach badania aktu administracyjnego wydanego przez organ główny. Georg Engelhard wskazał, że tylko pierwszy organ sam wydaje akt administracyjny, a organ współdziałający jedynie mu pomaga, zatem zaskarżony może zostać wyłącznie akt główny ${ }^{37}$. Postępowanie to nie ma bowiem samodzielnego bytu, a o treści rozstrzyga organ decydujacy, który w świetle prawa ponosi za nią pełną odpowiedzialność, także za szkodę spowodowaną niezgodnym z prawem rozstrzygnięcie, zgodnie z $§ 839$ $\mathrm{BGB}^{38}$. W niemieckim porządku prawnym, w przeciwieństwie do polskiego, organ rozstrzygający ma w stosunku do aktu zajęcia stanowiska także stanowczego, obarczonego wadą prawna, obowiązek kontroli jego legalności.

Sąd, kontrolując akt wielopoziomowy, dokonuje kontroli aktu zajęcia stanowiska. Jednolite postępowanie sądowe, w którym dokładnie analizowany jest wielopoziomowy akt administracyjny pod kątem legalności, jest całkowicie wystarczające, cechuje je większa efektywność, mniejsze koszty i lepsza ochrona adresata aktu wielopoziomowego aniżeli w przypadku odrębnej procedury skargowej na sam akt zajęcia stanowiska ${ }^{39}$. W przypadku gdy sąd uzna, że odmowa wydania zgody na wydanie pozytywnego rozstrzygnięcia przez organ główny jest niezgodna z prawem, to w wyroku upoważnia pierwszy organ (tj. główny) do wydania aktu administracyjnego bez uzyskiwania dalszej zgody organu współdziałającego.

35 Thienel (1996): 135.

36 Woywod (1968): 15.

37 Engelhard (1974): 53.

${ }^{38}$ Ustawa - Kodeks cywilny z 18 września 1986 r. (Bürgerliches Gesetzbuch in der Fassung der Bekanntmachung vom 2. Januar 2002 BGBl. I S. 42, 2909; 2003 I S. 738), das zuletzt durch Artikel 1 des Gesetzes vom 21. Dezember 2019 (BGBl. I S. 2911). Wöstmann (2020): nb. 66.

39 Forsthoff (1961): 197. 


\section{PODSUMOWANIE}

Organ współdziałający uczestniczy w załatwieniu sprawy przez wyrażenie stanowiska w zakresie swojej właściwości. Zarówno w Polsce, jak i w Niemczech organ współdziałajacy nie prowadzi samodzielnie postępowania głównego, lecz działa jedynie w ramach pewnego stadium postępowania w sprawie, która ma być załatwiona przez wydanie aktu administracyjnego. Obojętne, jakakolwiek by była forma współdziałania organów administracji realizowana w konkretnym przypadku na podstawie przepisów prawa materialnego, to organ współdziałający nie jest organem prowadzącym postępowanie w sprawie głównej, ale swego rodzaju asystentem, pomocnikiem, mającym szczególne kompetencje i wiedzę. Organ współdziałający uczestniczy jedynie w czynnościach danego postępowania, biorąc udział w załatwieniu sprawy przez wyrażenie stanowiska, wydanie opinii, skonsultowanie sprawy, w zakresie swojej właściwości. Stanowisko organu współdziałającego staje się podstawowym materiałem dowodowym w sprawie administracyjnej, czasem przesądzającym lub wręcz determinującym jej końcowe rozstrzygnięcie, stając się - gdy jest to stanowisko wiążące - elementem treści tego rozstrzygnięcia, a zatem kształtowanych nim praw lub obowiązków.

Istotną kwestią jest, aby praktyka organów administracji publicznej współdziałających z organami głównymi sprowadzała się do rzetelnego i kompleksowego wyjaśnienia przedstawionego stanowiska, a także do zapewnienia czynnego udziału w postępowaniu incydentalnym stronom postępowania głównego. Organy decydujące powinny chętnie sięgać po instytucję posiedzenia w celu współdziałania dla zwiększenia efektywności i przyspieszenia uzyskania niezbędnych stanowisk organów współdziałających.

$\mathrm{W}$ prawie niemieckim współdziałanie stanowi procedurę wewnętrzną powodująca, że akty zajęcia stanowiska mogą być kwestionowane w postępowaniu zmierzającym do oceny prawnej aktu głównego, co niewątpliwie pozwala na kompleksową kontrolę i uniknięcia nadmiernego wydłużenia się oczekiwania na wydanie decyzji głównej z uwagi na zaskarżenie aktów uczestnictwa $\mathrm{w}$ odrębnych postępowaniach. Większy nacisk kładzie się w prawie niemieckim na konsensualne dochodzenie do wspólnych uzgodnień przez organy administracji publicznej. Każda forma współdziałania sprowadza się do współdecydowania, wzbogacającego znacząco ustalenia faktyczne i prawne w sprawie i nadającego sens stosowania tego instrumentu prawnego. O szersze przyjmowanie regulacji polegajacych na współdecydowaniu organów należy postulować do ustawodawcy polskiego, a nadto o konsekwentne stanowienie poszczególnych form współdziałania w aktach normatywnych, celem zapewnienia właściwych skutków prawnych przez nie wywoływanych. Istotne dla rozwoju instytucji współdziałania materialnego w prawie polskim jest także ukształtowanie sprawiedliwych zasad odpowiedzialności organów współdziałających za podjęty akt administracyjny, tak aby organ rozstrzygający mógł zainicjować kontrolę ich legalności, zwłaszcza w przypadku stanowczych stanowisk, gdy już niekiedy gołym okiem widać ich rażącą niezgodność z prawem. 
Adamiak, B. (2019). Komentarz do art. 7b, [w:] B. Adamiak, J. Borkowski (red.), Kodeks postępowania administracyjnego. Komentarz. Warszawa: 83.

Biernat, S. (1979). Działania wspólne w administracji państwowej. Warszawa.

Błachucki, M. (2019). Ponadnarodowe sieci organów administracji publicznej oraz ich wpływ na krajowy porządek prawny. Warszawa.

Engelhard, G. (1974). Der mehrstufige Verwaltungsakt und seine prozessuale Behandlung. München.

Erbguth, W. (2017). Allgemeines Verwaltungsrecht: mit Verwaltungsprozessrecht und Staatshaftungsrecht. Baden-Baden.

Frischmann, J., Weingart, R. (1962). Zur selbständigen Anfechtbarkeit behördlicher Mitwirkungsakt. Die Öffentliche Verwaltung: 721-734.

Gruszecki, G. (2020). Komentarz do art. 77, [w:] T. Filipowicz, A. Plucińska-Filipowicz, M. Wierzbowski (red.), Ustawa o udostępnianiu informacji o środowisku i jego ochronie, udziale społeczeństwa w ochronie środowiska oraz o ocenach oddziaływania na środowisko. Komentarz. Warszawa: 482-497.

Kmieciak, Z. (2019). Komentarz do art. 106, [w:] W. Chróścielewski, Z. Kmieciak, A. Krawczyk, J. Wegner (red.), Kodeks postępowania administracyjnego Komentarz. Warszawa: 604-614.

Szewczyk, M. (2019). Faza trzecia: Opiniowanie i uzgadnianie planu miejscowego, [w:] Z. Leoński, M. Kruś, M. Szewczyk (red.), Prawo zagospodarowania przestrzeni. Warszawa: 314-320.

Müller, H. (2008). Kommetar § 5 ust. 4, [w:] G. Schulz (red.), Bundesfernstraßengesetz mit Autobahnmautgesetz. Kommentar. München: 57-60.

Muzak, G. (1995). Die Aufenthaltsberechtigung im österreichischen Fremdenrecht. Wien.

Niewiadomski, Z. (2011). Prawo administracyjne. Warszawa.

Pawłowski, S., Staniszewska, L. (2018). Konstrukcja milczącego współdziałania między organami administracji publicznej w świetle przepisów prawa materialnego, [w:] Z. Kmieciak, M. Gajda-Durlik (red.), Milczące załatwienie sprawy przez organy administracji publicznej. Warszawa: 365-389.

Ringhofer, K. (1977). Die österreichische Bundesverfassung: das Bundes-Verfassungsgesetz mit Kommentar, die wichtigsten verfassungsrechtl. Nebengesetze u. Staatsverträge sowie einfachgesetzl. Durchführungsvorschriften des Bundes. Wien.

Romańska, M. (2019). Komentarz do art. 106, [w:] A. Cebera, J. Firlus, A. Golęba, T. Kiełkowski, K. Klonowski, H. Knysiak-Sudyka, M. Romańska (red.), Kodeks postępowania administracyjnego. Komentarz. Warszawa: 154-170.

Rybicki, Z. (1984). Centralne układy kompetencyjne, [w:] Z. Rybicki, S. Piątek (red.), Zarys prawa administracyjnego i nauki administracji. Warszawa: 249-257.

Stahl, M. (2013). Szczególne prawne formy działania administracji, [w:] R. Hauser, A. Wróbel, Z. Niewiadomski, M. Stahl (red.), Prawne formy działania administracji. Warszawa: $315-401$.

Szewczyk, E. (2019). Współdziałanie organów administracji publicznej a decyzje zależne na przykładzie unormowań dotyczących planu ruchu zakładu górniczego. Studia Prawa Publicznego 2(26): 75-91.

Thienel, R. (1996). Der mehrstufige verwaltungsakt. Vien.

Wegner, J. (2016). Europejska współpraca administracyjna w projekcie reformy kodeksu postępowania administracyjnego. Europejski Przegląd Sądowy 6: 32-39.

Wöstmann, W. (2020). Komentarz § 839, [w:] J. Staudinger, J. Hager, H. Wöstmann (red.), Komentarz do BGB. Berlin. <https://www.otto-schmidt.de/online> [dostęp: 15.05.2020].

Woywod, U. (1968). Der mehrstufige verwaltungsakt. Bamberg.

Ziemski, K.M (1996). Zajęcie stanowiska a prawo bycia stroną postępowania administracyjnego (na przykładzie izby notarialnej). Rejent 2: 91-101.

Zimmerman, J. (2017). Aksjomaty prawa administracyjnego. Warszawa. 


\section{THE INSTITUTION OF SUBSTANTIVE COOPERATION IN ISSUING ADMINISTRATIVE ACTS ON THE EXAMPLE OF SELECTED LEGAL ORDERS - POLAND AND THE FEDERAL REPUBLIC OF GERMANY}

\section{Sum mary}

The article focuses on the issue of cooperation between public administration bodies, which aims to improve the administration. Cooperation is primarily a legal obligation, to the extent specified in a substantive legal norm, and the cooperating body is obliged to take this action in the appropriate form. In the discussed legal orders - Polish and German - there are many forms and gradations of cooperation. The article discusses issues associated with the legal nature of participation acts, as well as the auxiliary nature of the proceedings before the body obliged to take a position. The issue of the participation of the parties to the main proceedings before the cooperating body and models of judicial review of the act of participation are discussed. The conclusion of the article boils down to the thesis that the legislator needs to rethink the model of cooperation in Polish law, but also to improve the practice of its application.

Keywords: joint decision in an administrative matter; complex administrative acts; cooperation of public administration bodies 
